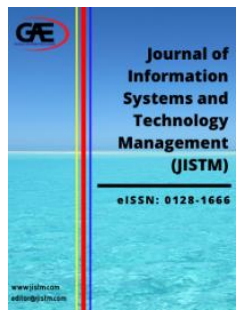

\author{
JOURNAL OF INFORMATION \\ SYSTEM AND TECHNOLOGY \\ MANAGEMENT (JISTM) \\ www.jistm.com
}

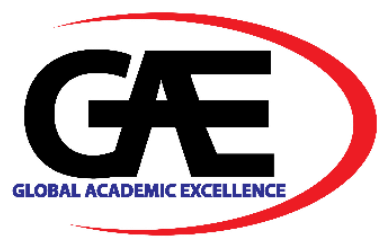

\title{
TEACHING AND LEARNING OF BIOLOGY PRACTICAL COURSES FOR FOUNDATION SCIENCE STUDENTS DURING COVID-19 PANDEMIC
}

\author{
Fadzilah Awang-Kanak ${ }^{1 *}$ \\ 1 Preparatory Centre for Science and Technology, Universiti Malaysia Sabah \\ Email: akfadzil@ums.edu.my \\ * Corresponding Author
}

\section{Article Info:}

Article history:

Received date: 11.09.2021

Revised date: 10.10 .2021

Accepted date: 15.11.2021

Published date: 30.11 .2021

\section{To cite this document:}

Awang-Kanak, F. (2021). Teaching and Learning of Biology Practical for Foundation Science Students During Covid-19 Pandemic. Journal of Information System and Technology Management, 6 (23), 128-135.

DOI: $10.35631 /$ JSTM.623011

This work is licensed under $\mathrm{CC}$ BY 4.0

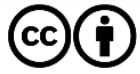

\begin{abstract}
:
This article aims to communicate several teaching and learning activities that were redesigned for biology practical courses for Universiti Malaysia Sabah's Foundation Science students during the restriction control movement (RMO) due to the Covid-19 outbreak. When RMO has been started the closure of the university campus resulted in postponed of biology practical face-to-face sessions in the laboratory. The teaching and learning activities have been guided by the Foundation Science Biology Laboratory Manual, however, during the pandemic, the delivery approach was modified using online platforms, including video-based blog or vlog, pre-recorded video, using realtime video conferencing i.e. Google Meet, Webex, scheduled online discussions via mobile apps i.e Whatsapp, Telegram, and greater utilization of Universiti Malaysia Sabah online learning platform, SmartV3UMS. The purpose of these redesigned methodologies that are presented in this paper was mainly focusing on delivering the established practical courses' contents to achieve the intended learning outcomes. A total of 353 students registered for these practical courses. They were divided into 16 groups, with 22 or 23 students per group. All these interventions have facilitated students to sustain their access to Foundation in Science study despite the physical engagement limitation and have opened a pathway to a new normal of science education.
\end{abstract}

Keywords:

Biology Practical, Foundation Science, Pandemic 


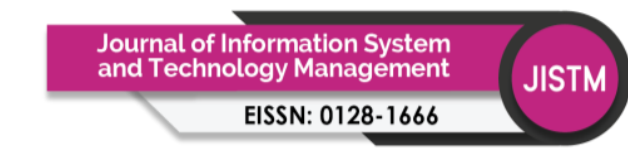

Volume 6 Issue 23 (November 2021) PP. 128-135

DOI: 10.35631/JISTM.623011

\section{Introduction}

Special Issue: Foundation Program Education Post-Covid-19: Issues and Opportunities

Practical courses have been essential modules in teaching and learning of science, technology, engineering and mathematics (STEM) (Zin, 2003; Blosser, 2011). Hands on practical courses have been proven to develop problem solving skills, scientific psychomotor abilities, scientific thinking, and intellectual development (Aktamiş \& Acar, 2010; Çifçili \& Kırbaşlar, 2015). The Coronavirus outbreak has been declared a pandemic by World Health Organization (WHO) in March 2020, and the Malaysian government announced the restriction movement order (RMO) started 18 March 2020 to flatten the virus infection (Junhairi, 2020). The RMO included the closure of schools, universities, and other premises. The sudden closure of universities enacted substantial challenges to teaching and learning activities, especially practical courses that involved the teaching of psychomotor skills (Amin, 2021). The shift was majorly involved changing the teaching and learning from face to face in the lecture hall and teaching laboratory to complete virtual or using online platforms (Chang, 2021). The change in delivery methodologies and teaching strategy with greater utilization of computer technology could enhance the learning opportunities for students despite the physical distance (Che Ahmad, 2021). However, it is important to note that education must be student centred, and technology is merely one of many tools in delivering teaching and experience learning. In the absence of technology for students, asynchronous learning (i.e. learning materials can be accessed without internet connection) should be applied.

Universiti Malaysia Sabah through E-learning Centre has provided an online learning portal, SMARTV3UMS, for blended learning purposes. During the weeks of RMO, this portal has been utilized by both lecturers and students to actively engage in online teaching and learning activities and also as mediums for online assessment e.g. quiz, online tests. Other than SMARTV3UMS, other mediums such as Google Meet, Webex, Google Drive, and mobile applications including Telegram and WhatsApp are also helpful to create academic communication bubbles among students, and between students and lecturers (Musa \& Abdillah, 2021). All these activities could direct the students to participate in active learning features such as collaborative learning, engagement in breakout sessions, live online survey (Darici, 2021).

There are two biology practical courses for Foundation Science Program, Practical Biology I SB0011 and Practical Biology II SB0021. Practical Biology I SB0021 includes experiments of Introduction to Microscopy, Prokaryotic and Eukaryotic Cells, Test for Organic Compounds, Human Reproductive System, Continuous and Discontinuous Variation. Meanwhile Practical Biology II SB0021, includes experiments of Monohybrid Cross in Corn, Enzymatic Reaction, Polymerase Chain Reaction, Inheritance of Blood Group. All these experiments were redesigned to suit the syllabus amendment for pandemic time. Both courses required both cognitive and psychomotor skills. During the pandemic, written laboratory tests were also modified to online multiple-choice questions quiz, the assessments were conducted by using SMARTV3UMS learning portal.

\section{Methodology}

\section{Redesigned Methodology of Teaching and Learning During Restriction Movement Order}

There are several methodologies that have been implemented for teaching and learning for Foundation Science biology practical courses during RMO. Including the implementation of a 


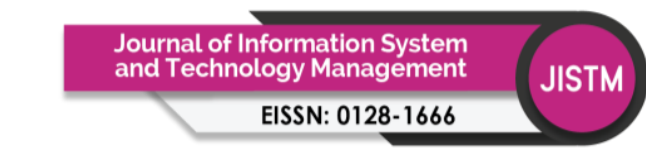

Volume 6 Issue 23 (November 2021) PP. 128-135

DOI: 10.35631/JISTM.623011

Special Issue: Foundation Program Education Post-Covid-19: Issues and Opportunities video-based blog or vlog for enzymatic reactions and inheritance of blood groups experiments, practical video for PCR simulation, and introduction to microscopy experiments, and using the Google Meet platform to run human reproductive system, continuous and discontinuous variation experiments and also for discussion among students and with laboratory demonstrators. It is important to note all these methodologies, merely focusing on delivering the established courses' contents. The student-teacher experience was not measured nor elaborated. These methodologies were done rather qualitatively, as the participation of students in the online classes were dictated merely by attendance, absent or present. All 353 registered students for practical courses were present during the online class. The participation were validated by using attendance extension in Google Meet, Google Form link that was shared via WhatsApp or Telegram, or screenshot of live visual image of the students.

\section{Video-Based Blog or Vlog}

The use of a video-based blog or vlog is an innovative teaching approach especially for practical sessions to help students understand and achieve the learning objectives of selected biology practical experiments (Che Ahmad, 2021). Due to shortening real-time face-to-face communication in the laboratory, students design and produce vlogs based on enzymatic reactions and inheritance of blood group experiments. The vlog would later be uploaded to the Google Drive platform and available for students to access post the laboratory session or asynchronously. Students in smaller practical groups could obtain data recorded in the vlog to revise and write practical reports.

Other than the vlog, peer teaching was also practiced and cooperated with the vlog, since the discussion of experimental results was done among students. The communication between students and laboratory demonstrators was done using various methods such as Google Meet, Telegram, or WhatsApp. Therefore, the vlogs and peer teaching approach could promote the engagement of the students in the learning process, increase self-confidence and improve coping mechanisms with the new learning environments during the pandemic time. The students' feedback on the vlogs approach was also collected in separate engagements.

\section{Practical Video for PCR Simulation Experiment.}

Polymerase Chain Reaction (PCR) is a technique that would amplify Deoxyribonucleic Acid (DNA) to million copies. PCR technique is widely applied in biotechnology and biomedical fields, including screening of genetic disease and coronavirus detection (Phan, 2006). The concept of PCR is taught in both theory and practical courses. The experiment of PCR simulation was designed by using familiar tools, such as scissors, sticky tape, and pencil, and this enables us to do PCR simulation experiments remotely. Double strand 'paper' template DNA is available for students in Biology Laboratory Manual. Students can print the template and use it for the practical sessions.

Pre-recorded video for PCR simulation was prepared and made available via Youtube channel and shared link in the SMARTV3UMS learning portal. Students may access the video asynchronously and experience distance learning when they were doing PCR simulation experiments. Laboratory demonstrators may assist students to understand the role of the experiment instruments (i.e scissors, sticky tape, pencil, template DNA) and compare those instruments with real PCR materials and techniques. For example, scissors represent the hightemperature denaturation step $\left(95^{\circ} \mathrm{C}\right)$ in PCR. This high temperature will break the hydrogen 
Volume 6 Issue 23 (November 2021) PP. 128-135 DOI: 10.35631/JISTM.623011

Special Issue: Foundation Program Education Post-Covid-19: Issues and Opportunities bonds between two DNA strands. In the simulation, DNA strands are represented with a paper template.

\section{Google Meet Platform for Continuous and Discontinuous Varaiations and Human Reproductive System Experiments}

Google Meet is a live video application that is freely available and easily used by users worldwide. Its friendly user interface with chat, recording functions make it a preferable video application among students (Musa \& Abdillah, 2021). Google Meet has been widely used by many lecturers, teachers, students as a medium for virtual classes, discussions, or meetings. For Biology Practical, continuous and discontinuous variations experiment, set two objectives for students. At the end of the experiment session, students should be able to identify and compare between continuous and discontinuous variations. They also should be able to measure and record discrete and continuous data accurately. Continuous variation is when there is a range in measurement of characteristics, for example height and weight of students. Continuous variation caused by polygenic inheritance could be influenced by environmental factors and individual activities. Discontinuous variation is where individuals can be categorized into class or group. Blood group is an example of discontinuous variation, it is controlled by alleles of a single gene or a small number of genes. The environment would not affect this type of variation (Campbell, 2018).

Materials needed for this experiment for face-to-face sessions are meter stick or measuring tape, beam balance, paper, pencils, and tape or string. However, since this experiment was conducted online, students could collect data from their student's personal information i.e (weight, height, blood group). Simple survey distributed to students via online application, and this survey enables data for continuous and discontinuous can be collected. Table 1 shows data of human physical characteristics and abilities that was collected during an online survey. Figure 1 and Figure 2 are examples of continuous and discontinuous variation data collected from experiment by the students.

Table 1: Human Physical Characteristics and Abilities

\begin{tabular}{c}
\hline Characters/Abilities \\
Hitchhiker thumb \\
Widow's peak \\
Left or right interlocking finger \\
Chin fissure \\
Short big toe \\
Dimple \\
Tounge rolling ability \\
Preparatory Centre for Science and Technology Biology Laboratory Manual
\end{tabular}


Volume 6 Issue 23 (November 2021) PP. 128-135

DOI: 10.35631/JISTM.623011

Special Issue: Foundation Program Education Post-Covid-19: Issues and Opportunities

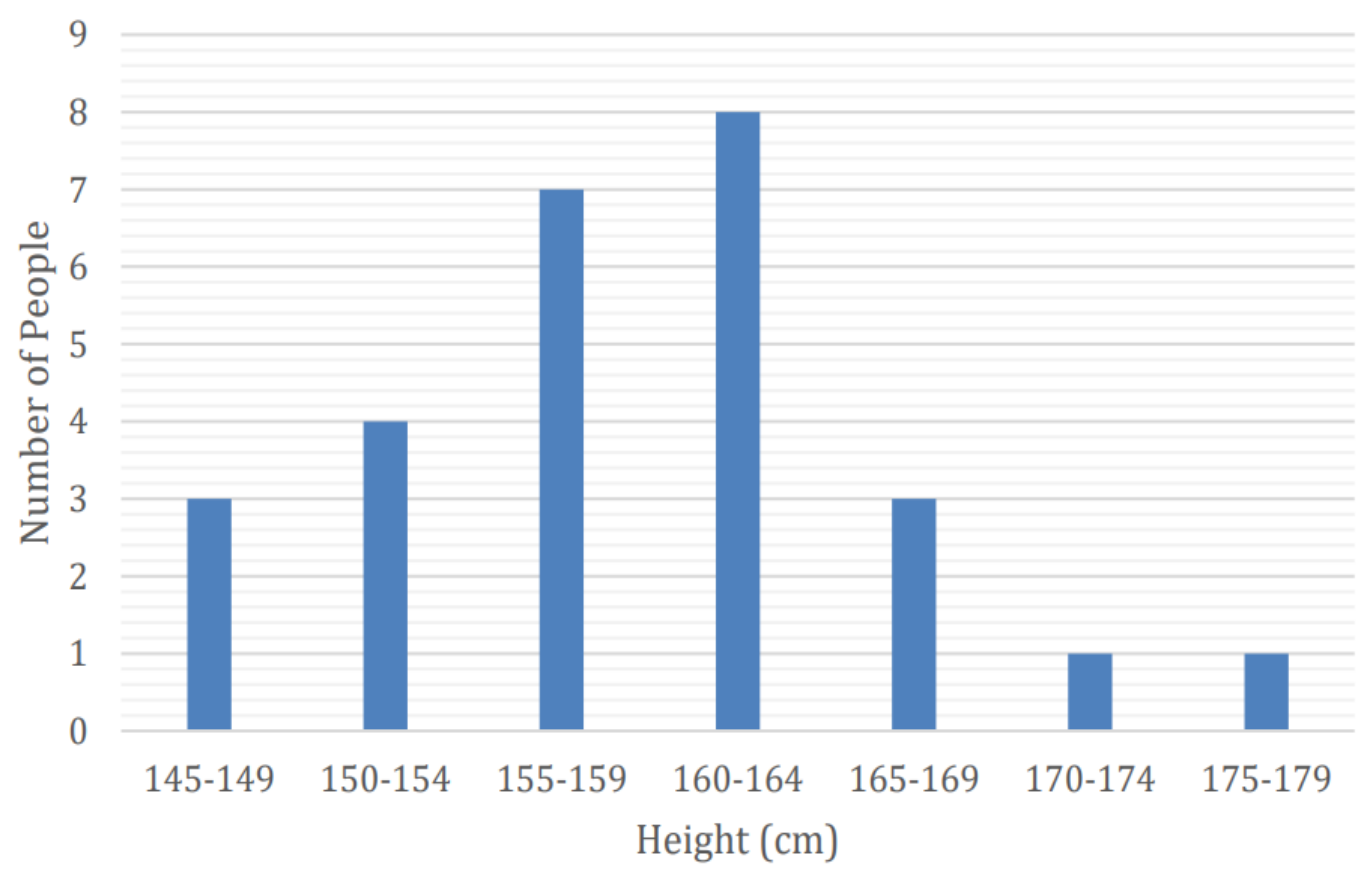

Figure 1: Continuous Variation Data, Height of Students. Graph Was Created by Students by Using Data from Online Survey.

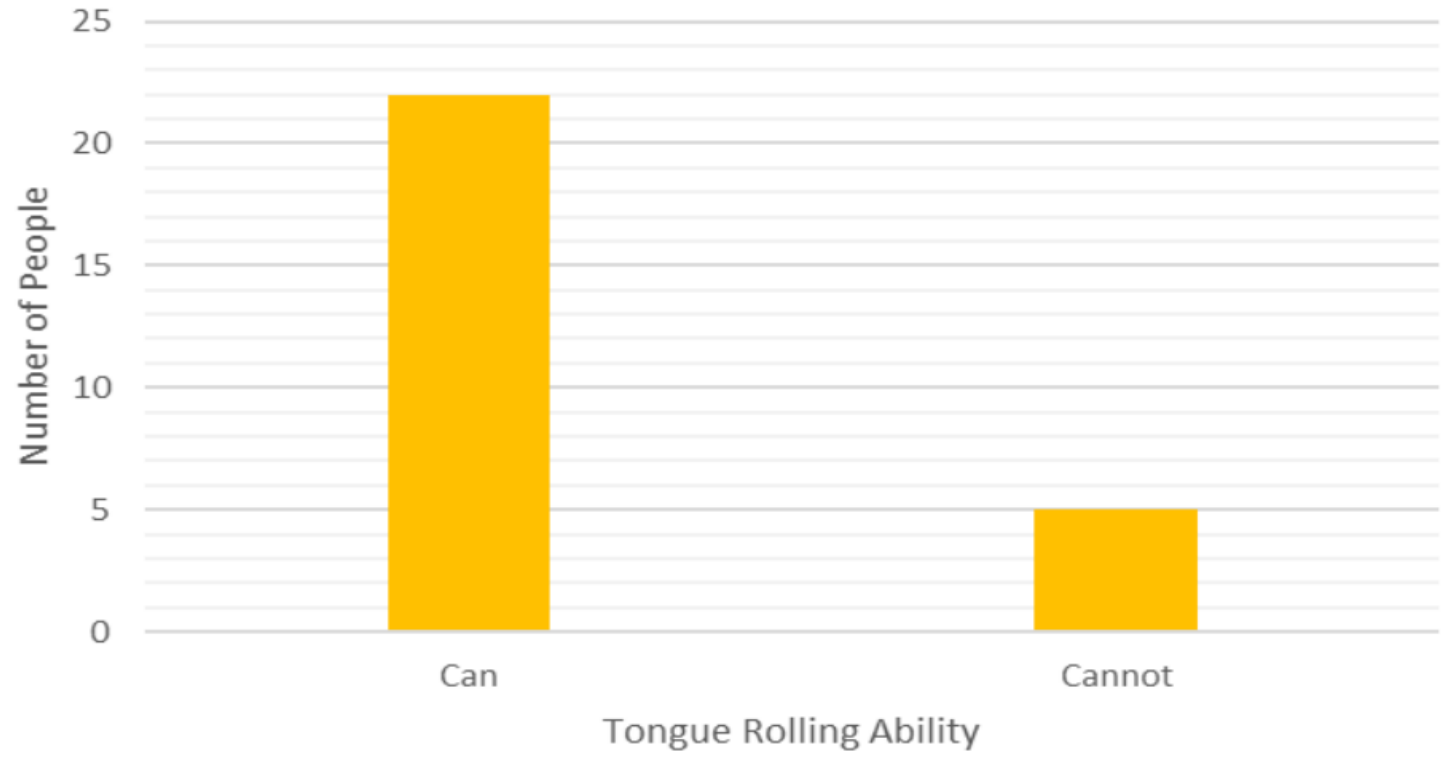

Figure 2: Discontinuous Variation Data, Tongue Rolling Ability Among Students. Graph Was Created by Students Using Data Collected from Online Survey.

In human reproductive system experiment, students are required to describe cyclical hormonal changes in women of reproductive age via Google Meet session. Students would create a graph of relative female's hormone level and this graph would assist students to determine hormonal changes during menstrual cycle. Materials needed for this task, graph paper and coloured pencils. Students in smaller group would have their breakout session and discussed in other Google Meet room with their practical group. After given 30 minutes to discuss and create their 
Volume 6 Issue 23 (November 2021) PP. 128-135 DOI: 10.35631/JISTM.623011

Special Issue: Foundation Program Education Post-Covid-19: Issues and Opportunities graph, all students would re-join the main Google Meet room to present their result and discussion with guidance from demonstrator. Figure 3 shows the Google Meet room during result and discussion presentation.

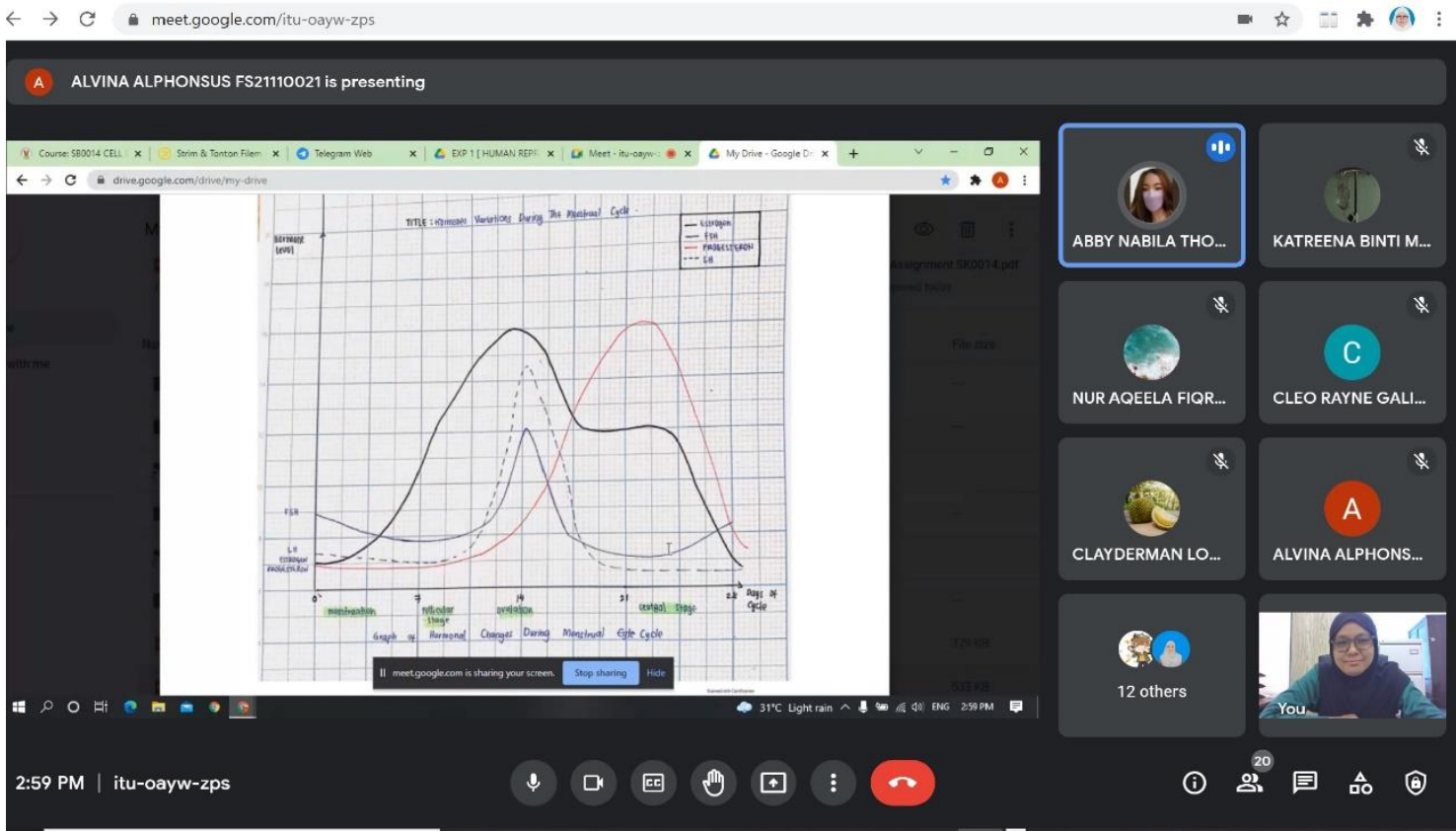

Figure 3: Presentation of Result and Discussion by Students Using Google Meet Platform.

\section{Discussion}

The changes from physical laboratory to virtually conducted experiments were not a gradual process during Covid19 pandemic, but rather abrupt. Before 2020, Foundation Science study has still practiced face to face learning in conventional laboratories and classrooms in order to achieve the intended courses' learning outcomes that include cognitive and psychomotor skills (Awang-Kanak, 2016; Masnoddin, 2018; Matawali, 2019). Many schools and higher learning institutions in Malaysia and all over the world have adjusted and redesigned their teaching or delivery methods to adapt with the requirements of preventing spread of Covid19 disease by observing strict social distancing (Che Ahmad, 2020; Amin, 2021; Chang, 2021). The changes are not just a gauntlet task for academic providers (i.e., university, lecturer), but also for students and their families, since the conducive environment for learning is now shifted to their personal space, at home or dormitories. Several problems have risen along this course of online teaching and learning, includes poor internet connection, device impairment, and heavy traffic of users that have caused access disruption to SMARTV3UMS learning portal, Despite the hurdles, be it technological constraint, or skill acquisition, there were previous studies that show online learning for practical courses (laboratory-based learning) do not compromise the student performance, and positive attitude among students who experienced virtual laboratory session are also reported (Ambusaidi, 2018; Amin, 2021; Chang 2021, Darici, 2021).

\section{Conclusion}

Teaching and learning biology practical courses are facing swift changes from blended learning that combined physical laboratory and online learning portal to complete online delivery that rely heavily on internet connectivity, technological skills, and digital devices. There are several Copyright (C) GLOBAL ACADEMIC EXCELLENCE (M) SDN BHD - All rights reserved 
Volume 6 Issue 23 (November 2021) PP. 128-135 DOI: 10.35631/JISTM.623011

Special Issue: Foundation Program Education Post-Covid-19: Issues and Opportunities issues that need to be studied further regarding virtual laboratory sessions for Foundation Science Program in Universiti Malaysia Sabah. These issues include student perspective, teacher's readiness to deliver virtual sessions, the effectiveness of online learning on student's performance, and setting consistent quality standards on virtual laboratory sessions that could have great impact on students' psychomotor and laboratory related skills.

\section{References}

Aktamiş, H. \& Acar, E. (2010). The effect of "laboratory practices in science teaching" course on development of prospective science teachers' self- regulation skills. Procedia Social and Behavioral Sciences, 2(2), 5549-5553

Ambusaidi, A., Al Musawi, A., Al-Balushi, S., \& Al-Balushi, K. (2018). The impact of virtual lab learning experiences on 9th grade students' achievement and their attitudes towards science and learning by virtual lab. Journal of Turkish Science Education, 15(2), 1329.

Amin, H. A. A., Khalil, H., Khaled, D., Mahdi, M., Fathelbab, M., \& Gaber, D. A. (2021). Case item creation and video case presentation as summative assessment tools for distance learning in the pandemic era. Medical Journal Armed Forces India, 77, S466S474.

Awang-Kanak, F., Masnoddin, M., Matawali, A., Daud, M. A., \& Jumat, N. R. (2016). Difficulties experienced by science foundation students on basic mendelian genetics topic: A preliminary study. Transactions on Science and Technology, 3(1-2), 283-290.

Blosser, P. E. (2011). The Role of the Laboratory in Science Teaching. NARST: Publications -- Research Matters - to the Science Teacher, 97(4), 13-15.

Cambell, N.A., Urry, L.A., Cain, M.L., Wasserman, S.A., Minorsky, P.V., Reece, J.B. (2018). Biology - A global approach. 11 uppl. USA: Pearson education limited.

Chang, J. Y. F., Wang, L. H., Lin, T. C., Cheng, F. C., \& Chiang, C. P. (2021). Comparison of learning effectiveness between physical classroom and online learning for dental education during the COVID-19 pandemic. Journal of Dental Sciences, 16(4), 12811289.

Che Ahmad, C. N. (2020). Pembangunan modul Video Amali (V-Lab) bagi mempertingkatkan pengajaran dan pemudahcaraan biologi tingkatan empat. Jurnal Pendidikan Sains Dan Matematik Malaysia, 10(2), 1-7.

Çifçili, V. \& Kırbaşlar, F. G. (2015). Investigating Perceptions of Pre-service Science Teachers towards Laboratories by Using Phenomenological Pattern. Procedia - Social and Behavioral Sciences, 174, 1371-1378.

Darici, D., Reissner, C., Brockhaus, J., \& Missler, M. (2021). Implementation of a fully digital histology course in the anatomical teaching curriculum during COVID-19 pandemic. Annals of Anatomy-Anatomischer Anzeiger, 236, 151718.

Junhairi Alyasa (2020). Covid-19: Perintah Kawalan Pergerakan di seluruh negara bermula 18 Mac. Retrieved from https://www.sinarharian.com.my/article/74100/KHAS/Covid19/Covid19-Perintah-Kawalan-Pergerakan-di-seluruh-negara-bermula-18-Mac

Masnoddin, M., Kiram, J. J., Matawali, A., \& Jumat, N. R. (2018). Improving pre-university students' understanding of basic plant tissue culture topic through laboratory teaching: a case study of UMS. Transactions on Science and Technology, 5(1), 53-57.

Matawali, A., Bakri, S. N. S., Jumat, N. R., Ismail, I. H., Arshad, S. E., \& Din, W. A. (2019). The Preliminary Study on Inverted Problem-Based Learning in Biology among Science 
Volume 6 Issue 23 (November 2021) PP. 128-135

DOI: 10.35631/JISTM.623011

Special Issue: Foundation Program Education Post-Covid-19: Issues and Opportunities Foundation Students. International Journal of Evaluation and Research in Education, 8(4), 713-718.

Musa, M., \& Abdillah, N. A. (2021). Penggunaan Google Meet dalam Proses Pengajaran dan Pembelajaran di Politeknik Sultan Mizan Zainal Abidin. Journal of Modern Education, 3(8), 104-113.

Zin, S. M. S. (2003). Reforming the science and technology curriculum: The Smart School Initiative in Malaysia. Prospects, 33(1), 39-50. 